\title{
VENTURE INVESTMENTS AS A PROSPECTIVE DIRECTION OF ACTIVATION OF INNOVATIVE ACTIVITY
}

\author{
Halyna Hrynyshyn ${ }^{1}$
}

\begin{abstract}
The purpose of this article is to study the intensification of venture investment in innovation processes in Ukraine, to identify problems and promising areas of development of the venture industry. The article considers the essential characteristics of the economic category "venture investments" and "investments", comparative analysis and the relationship between them. The main advantages and disadvantages of venture investment, values and main forms are highlighted. The sequence of stages of venture financing and types of schemes of venture financing are given. Venture capital entities are considered. The main stages of formation of the venture industry in Ukraine are revealed. Methods of analysis and risk assessment of the investment project are offered. The main types of strategies for minimizing risks in venture investing are presented. Among the considered strategies the most promising are strategies implemented with the participation of third parties, as in this case the maximum effect from a point is reached view of the national economy. Object of research. Venture capital in the system of financing innovation processes in the modern economy. The subject of the research is theoretical methodological and applied aspects of the functioning of venture capital as a source of financing innovation processes in Ukraine. The methodological basis of the study is a set of general and special methods of cognition. Methods of analysis and synthesis, generalization and scientific abstraction were used in the formation of the conceptual and categorical apparatus. The analysis of approaches to understanding the essence of venture investment, its components was carried out using dialectical and systemic-structural methods. The application of the historical-logical method, induction and deduction made it possible to study the genesis of the theory of economics and enterprise management, the factors of the strategy of development of venture investment of business entities. Within the framework of the study of the current state of venture investment, calculation and analytical methods of observation, measurement, analysis and comparison are used. Conclusions. It is proved that venture investment only has a positive effect on accelerating innovation processes in the economy when it performs its main function - investing in small innovative enterprises that implement their progressive ideas, providing positive innovative changes in the production structure in favor of high-tech systems. The essence of the influence of venture capital on innovation processes is manifested only through its main function - venture investment.
\end{abstract}

Key words: innovation, venture capital, venture investment, bankruptcy, profitability, financial institutions, risks, startups.

JEL Classification: E20, E27, E62, F21, O31

\section{Introduction}

In the conditions of unstable macroeconomic and political situation that has developed today in Ukraine, inflows of foreign investments are extremely necessary for economic recovery. One of the tools for implementing financial mechanisms could be venture investment, which involves financing new, risky projects or unprofitable companies in order to increase their capitalization. In addition to being an alternative source of financing and business development, venture capital investments can also serve as an effective source of financial support for research and development into a competitive product, which is an important factor in Ukraine's foreign economic activity towards European integration. Mega-giants of computer and information business were formed from small innovative companies such as HP, Microsoft, Apple, Oracle, Yahoo, Amazon, Google, Intel, due to the inflow of venture capital. That is why the further development of venture investment is especially relevant in today's conditions.

\footnotetext{
Corresponding author:

${ }^{1}$ Stepan Gzhytskyi National University of Veterinary Medicine and Biotechnologies Lviv, Ukraine.

E-mail: H0802@meta.ua

ORCID: https://orcid.org/0000-0001-5224-9631
} 
The methodological basis of the study is a set of general scientific and special methods of cognition. Methods of analysis and synthesis, generalization and scientific abstraction were used in the formation of the conceptual and categorical apparatus. The analysis of approaches to understanding the essence of venture investment, its components was carried out using dialectical and systemic-structural methods. The application of the historical-logical method, induction and deduction made it possible to study the genesis of the theory of economics and enterprise management, the factors of the strategy of development of venture investment of business entities. Within the framework of the study of the current state of venture investment, calculation and analytical methods of observation, measurement, analysis and comparison are used.

The most significant works in the world theory and practice of venture investment are the works by A. Dagaev, A. Korzhauv, K. Campbell, M. Neubert, P. Robertson, I. Skoblyakova, A. Folomiev, T. Hellmann. World economics studies the problems of venture capital in a developed market economy, namely - the knowledge economy. In Ukraine, the conditions for the development of venture capital are just being formed. Theoretical and methodological problems of its formation are reflected in the works of famous domestic economists, among which there should be noted the works by O. Amosha, L. Antoniuk, I. Grozny, G. Demyanchuk, M. Dyba, Y. Drachuk, I. Egorov, A. Zagorodny, E. Zadorozhny, O. Krasovska, M. Krupka, O. Kuzmina, O. Lapko, N. Matseliukha, V. Novikov, I. Odotiuk, A. Poruchnyk, T. Smovzhenko, I. Sofishchenko, A. Stepanenko, O. Yurkevich and others. However, it should be noted that the domestic economic literature lacks thorough scientific and practical developments on the causes, acceptable limits and socio-economic consequences of investing in high-risk innovation projects. Therearealmostnoscientificdevelopments to analyze the economic preconditions of venture investment in innovation; there are not developed approaches to quantitative assessment of venture investment risks; organizational and legal principles for implementation of venture financing are not legally established.

\section{The essence of venture investment}

The term "venture" means "risk", "risky business", "dare", in general, all its definitions are somehow related to courage and adventure.
Venture capital is one of the oldest types of capital. It comes from the moment when a person who came up with an innovative business idea asked his or her relatives or friends to invest a certain amount of money in his or her business, offering part of the profits in the future. Americans jokingly say that "sources of investment in a new business can be three " $f$ ": family, friends, fools (Oliver, 1996).

In world and domestic economics there are various interpretations of the definition of venture capital. Some define venture capital as investing in risky, innovative, high-yield projects in promising industries or even business ideas. Others prefer a broader interpretation, which includes any financing for the company's rapid growth. Thus, in this case, venture capital finances not only the formation of startup capital, but also the next stages of formation of an innovative enterprise. Venture capital is a link between investment and innovation as components of economic growth, a source of capital for companies whose rapid growth and development constantly requires additional foreign investment (usually small and medium-sized enterprises).

The main difference between venture capital investment and traditional investment is that financial assets are provided to the company without any guarantee of provision of movable or immovable property or savings. The only guarantee is the relevant part of the shares, less than the controlling stake of the existing or just created company, scilicet venture capital is provided to the company for a promising idea.

I. Dvorzhak, Ya. Kochyshova and P. Prokhazka emphasize the focus of venture capital on high risk and the implementation of scientific and technological innovations, based on empirical analysis of venture capital in the Anglo-Saxon model (the USA, Canada, the UK) and innovationoriented capital in Western Europe (Krasovska, 2013).

World-renowned venture capitalist Tim Draper believes: "Venture business is when 10 companies invest, half of them go bankrupt, three return, one gives a 10 -fold increase, and another profit is 100 times higher than the investment" (Zinchenko et al., 2004). The expectation of making extremely high profits also forces the venture capitalist to take exorbitant economic risks.

Experts of the British Private Equity and Venture Capital Association (BVCA) interpret venture capital investments as investments in the share 
Vol. 1, No. 2, 2020

Table 1

Comparative assessment of venture and traditional investment

\begin{tabular}{|c|c|c|}
\hline Comparative characteristics & Venture investments & Traditional investments \\
\hline Market distribution & $\begin{array}{l}\text { The venture investor shares the risks with } \\
\text { the owners of the firm }\end{array}$ & $\begin{array}{l}\text { The traditional investor has priority in making } \\
\text { a profit and returning funds in the event of } \\
\text { bankruptcy before the owners }\end{array}$ \\
\hline $\begin{array}{l}\text { Enterprises are recipients of } \\
\text { investments }\end{array}$ & $\begin{array}{l}\text { Small, high-tech companies starting a } \\
\text { business }\end{array}$ & $\begin{array}{l}\text { Companies that already have enough capital } \\
\text { to cover possible losses and successful market } \\
\text { experience }\end{array}$ \\
\hline $\begin{array}{l}\text { Criteria for selecting an } \\
\text { enterprise }\end{array}$ & Potential growth opportunity & High profitability \\
\hline Investor functions & $\begin{array}{l}\text { Provision of capital, management } \\
\text { consulting, use of investor relations in the } \\
\text { markets of supply, finance, marketing, sales }\end{array}$ & Provision of capital \\
\hline Providing security & Without security & Collateral security \\
\hline Profit & $\begin{array}{l}\text { Sale of shares of the company after the } \\
\text { increase in their value }\end{array}$ & $\begin{array}{l}\text { Fixed percentage of invested funds or from the } \\
\text { implementation of the investment project }\end{array}$ \\
\hline
\end{tabular}

Source: based on (Shypulina, 2015)

capital of companies not listed on stock exchanges, which are both in the initial and later stages of development, when the acquisition of the company requires significant financial resources.

Representatives of the European Venture Capital Association interpret venture capital as risky financing, which involves equity participation in the company's capital and management support.

The Australian Private Equity and Venture Capital Association Limited (AVCAL) offers slightly different definitions of venture and private equity. According to its definition, venture capital is capital that has independent management and is invested in private companies with high growth rates.

The set of these definitions does not fully reveal the functional features of venture capital, which has a more complex economic nature. However, we can summarize that venture capital is a special form of resource that combines financial and intellectual capital invested in an innovative project with a high level of risk and significant potential for commercialization of the idea embodied in the new product. It should be noted that the main feature of venture capital is its dependence on the human factor. It is people with their intellectual capital who form the basis of the functioning of this market.

Considering venture capital in the system of innovation processes in the economy, it should be noted that it is a critical factor in the innovation process. Venture capital by its nature is reproduced through features that are unique to it: constant relationships with innovation, science, and technology; a combination of financial capital and intellectual resources; high level of risk; dispersion in the financing of innovative projects; different levels of income in certain phases of its life cycle. Thus, the venture capital market, which belongs to the type of markets of imperfect competition, is characterized by manifestations of asymmetry: uneven distribution of information between the subjects - venture capitalists and consumers (recipients) of capital.

The subjects of the venture capital market are:

1) venture investors - legal entities and individuals who invest in risky companies;

2) enterprises-addressees of venture capital - those who dispose of funds received from investors and invest them in various innovative projects;

3) risk capital recipients - companies financed by venture capital.

Another characteristic feature of venture capital is the scattered financing of innovative business projects and different levels of profit at different stages of its life cycle. Venture capital financing can be divided into several stages. Each of these stages is characterized by problems that require specific professional and technical solutions. This transfer of life cycle phases to venture capital allows us to identify several stages of the cycle of use of venture capital (Table 2).

The main function of venture investors in financing venture enterprises is manifested at the stages of seed (development) and startup (start). In these sets, venture capital support is combined with intensive management advice to a new venture capital company. After successfully entering the market, the venture capitalist supports the firm in the search for other external sources of capital. 
Table 2

Stages of the life cycle of venture capital

\begin{tabular}{|c|c|c|}
\hline \multicolumn{3}{|c|}{ Stages of formation and development of innovative companies } \\
\hline Name & Characteristic & Volumes of capital \\
\hline $\begin{array}{l}\text { Seed } \\
\text { Initial "sowing" }\end{array}$ & $\begin{array}{l}\text { Forming a company, having a project or business idea, the process of creating a } \\
\text { management team, the beginning of marketing research. }\end{array}$ & $\begin{array}{l}\text { Requires attachments } \\
\text { to } 1 \text { million USD }\end{array}$ \\
\hline $\begin{array}{l}\text { Startup } \\
\text { Launching }\end{array}$ & $\begin{array}{l}\text { The company is formed. There is a business plan, prototypes, the organization } \\
\text { of mass production and activities to bring products to market. }\end{array}$ & $\begin{array}{l}\text { Requires investments from } \\
1 \text { up to } 5 \text { million USD }\end{array}$ \\
\hline Early growth & $\begin{array}{l}\text { Production and sale of finished products are carried out. The company still } \\
\text { lacks a steady profit. At this stage there is an exit to the "break-even point". }\end{array}$ & $\begin{array}{l}\text { Requires investments from } \\
5 \text { up to } 10 \text { million USD }\end{array}$ \\
\hline Expansion & $\begin{array}{l}\text { The company's occupation of certain market positions, access to sustainable } \\
\text { profitability, expansion of production and sales, conducting additional } \\
\text { marketing research, increasing fixed assets and capital. }\end{array}$ & $\begin{array}{l}\text { Requires investments of } \\
\text { more than } 10 \text { million USD }\end{array}$ \\
\hline $\begin{array}{l}\text { Later stage } \\
\text { Resistant } \\
\text { development }\end{array}$ & $\begin{array}{l}\text { Strong positions in target markets, stable profits and dividend payments. The } \\
\text { values of annual growth are small. The company's shares can be sold on the } \\
\text { stock exchange. }\end{array}$ & $\begin{array}{l}\text { Investments depend on } \\
\text { need }\end{array}$ \\
\hline
\end{tabular}

Source: own study

\section{Formation and development of the venture industry in Ukraine}

The beginning of international venture investment in Ukraine is considered to be 1993, when the Tokyo Summit between the governments of the G7 and the European Union adopted an Agreement to support newly privatized enterprises under the State Program of Mass Privatization, under which about 15,000 small and medium enterprises worked.

The creation of venture funds in Ukraine can be divided into several stages. The first period is considered to be 1992-2001, which is characterized by the creation and operation of 7 venture funds in Ukraine through foreign investment.

Since 1994, another venture fund "Western Nis Enterprise Fund" with a capital of 150 million USD has been operating in Ukraine, and in 1998, it began to operate on the Black Sea Fund. These two funds are still operating successfully. A large share of funding from these funds is provided by the European Bank for Reconstruction and Development. In the same year, Evroventures Ukraine (capitalization 30 million USD) was established and began operations in 1999.

Between 1994 and 1996, 11 regional venture funds were gradually established in partnership with the European Bank for Reconstruction and Development (EBRD), which provided 310 million USD. US equity financing in Kyiv, and donor countries (France, Germany, Italy, Japan, USA, Finland, Norway and Sweden), which provided 207 million USD in unpaid loans.
The second stage of development of venture funds is considered to be 2001. According to the Ukrainian Investment Business Association, in 2004-2010, the number of venture funds increased 13.9 times and the value of net assets increased 63.1 times, the growth rate of these indicators slowed more than 2 times during this period, the largest slowdown was observed after the global financial crisis in 2008 (Parubchak, Hrynyshyn, 2020).

In December 2005, Draper Fisher Jurvetson (DFJ), which includes 20 funds with a total investment capital of more than 3 billion USD, opened the DFJ Nexus technology venture fund in Ukraine. Over the next 10 years, the fund plans to raise from 50 to 100 million USD for the development of high-tech companies in the countries of the former USSR.

We consider the period up to 2008 to be the third stage of venture business development in Ukraine. In 2008, the State Agency for Investment developed a draft Law of Ukraine "On Venture Funds for Innovative Development". For the first time in Ukraine, the bill attempts to define the legal basis for the creation of a new financial instrument that would ensure the direction of investment flows into innovative sectors of the economy. This document states the following: the founders and participants (shareholders) of the venture fund of innovative development may be individuals and legal entities, residents and non-residents, as well as the state and local communities; venture capital funds can invest in corporate rights and debt obligations of innovative enterprises; joint ventures established 
to implement technology parks and science parks; Venture capital assets of innovative development may consist of corporate rights, debt obligations, real estate and intellectual property rights; venture funds of innovative development invest in innovative programs and projects, new knowledge and intellectual products, production equipment and processes, infrastructure of production and entrepreneurship, etc.

The fourth stage is the post-crisis year of 2009, which is characterized by a slowdown in the growth rate of CII assets. 2014 was one of the most difficult years for the Ukrainian sector of asset management of institutional investors, as well as for the whole country, in the previous history, political instability, annexation of Crimea, military actions in the east, devaluation of assets, numerous attempts to fill the budget and change mechanisms for taxing the activities of collective investment institutions, the outflow of investors, but even such negative factors were not as destructive as might be expected. At the end of 2014, the assets of venture companies amounted to 202.85 billion UAH.

Since 2014, the Ukrainian Venture and Private Capital Association (UVCA) has been creating a positive image of Ukraine in the world and promoting Ukrainian startups, uniting about 50 venture funds, direct investment funds, accelerators, incubators and non-profit institutions. The next stage of venture business development is 2017, which became a record in the history of Ukrainian venture business startups raised 258.6 million USD, which is three times more than in 2016. This confirms the fact that Ukrainian startups create highly competitive products that can meet the needs of consumers around the world. In recent years, we have seen a steady growth of the Ukrainian investment market. Although the COVID-19 outbreak has made some adjustments to investor plans and startup development, understanding the trends of 2019 will be useful for investment market players to manage expectations, support and grow their business in the new reality.

\section{Analysis of risks and their minimization in the implementation of venture capital}

Venture capital investment is a long-term financial investment with a high degree of risk in the shares of newly created small innovation and technology firms, which are focused on the development and production of knowledgeintensive products, in order to profit from the increase in the value of invested capital in a particularly short time.

Any activity that involves money carries a certain risk. Similarly, venture capital investment has certain risks in its activities, which are manifested in the following:

1. These investments are directed to those companies whose shares are not listed on the stock exchange. That is, investments do not flow into those companies that are already profitable in the market, having a certain customer base, young but promising companies that are potentially able to increase the money invested in them.

2. Venture capital investments are invested for a long time, and the investor has no opportunity to return their money before its completion.

3. Typically, such investments are directed to companies that have some "highlight", an innovation that will either bring a profit or fail miserably.

According to analytical observations, about $15 \%$ of risky companies are unsuccessful, $25 \%$ are unprofitable, i.e. lose more than they earn, $30 \%$ can be considered unprofitable, and only $30 \%$ of venture companies make a profit that compensates for the losses of other ventures (Ukrainian venture portal).

Investment risk analysis is the main stage of the innovation project analysis in case of venture capital inflows. As part of the risk study, the problem of reconciling two practically opposite aspirations is solved: profit maximization and project risk minimization.

Investment risk analysis is performed using mathematical models of decision making: stochasticmodels; linguistic (descriptive) models; game, behavioral models. Systematization of the characteristics of the most common methods of analysis and risk assessment is presented in Table 3.

The analysis and assessment of the risks of venture financing of innovative projects should also take into account the characteristics of venture capital. The main feature of venture capital investment is that free funds are invested mainly in small or medium-sized enterprises with an innovative focus, which, for the most part, do not provide the investor with any collateral or guarantees. In addition, the venture investor does not intend to acquire a significant stake or controlling stake in the company in which he or she invests, but 
Table 3

Methods of analysis and risk assessment of an innovative project

\begin{tabular}{|c|c|}
\hline Method & Characteristics of the method \\
\hline Expert methods estimates & $\begin{array}{l}\text { A set of methods for forecasting and risk analysis formed on the experts' conclusions. The most } \\
\text { commonly used methods of expert risk assessment: the Delphi method, ranking, scoring method. } \\
\text { Probability of the obtained assessments, which summarizes the opinions of experts, depends } \\
\text { on the qualification experts, the independence of their judgments, as well as methodological } \\
\text { support expertise. One of the indicators of the probability of the obtained values is the efficient } \\
\text { concordance (agreement) of experts' opinions. }\end{array}$ \\
\hline Simulation methods & $\begin{array}{l}\text { Based on the step-by-step determination of the performance indicator due to conducting } \\
\text { multiple experiments with the model. Their main advantages are: transparent calculations, ease of } \\
\text { perception and evaluation of the results of the project analysis by all participants in the planning } \\
\text { process. It is necessary to indicate the significant costs of calculations associated with large } \\
\text { volume source information as one of the disadvantages of this method. }\end{array}$ \\
\hline $\begin{array}{l}\text { Scenario analysis } \\
\text { development }\end{array}$ & $\begin{array}{l}\text { The method involves the development of several options (scenarios). Calculated worst case } \\
\text { scenario of possible change of variables, optimistic and most probable option. }\end{array}$ \\
\hline Probabilistic analysis & $\begin{array}{l}\text { It is assumed that the construction and calculations of the model are carried out in accordance with } \\
\text { principles of probability theory. The probability of losses is determined on the basis of statistical data } \\
\text { of the previous period with the establishment of the area (zone) of risks, risk factor. }\end{array}$ \\
\hline $\begin{array}{l}\text { Method of analogy in risk } \\
\text { management }\end{array}$ & $\begin{array}{l}\text { Using a database of similar projects to transfer their results activity on the project under } \\
\text { development. This method is used if the internal and external environment of the project and its } \\
\text { analogues has sufficient convergence according to the main parameters. It is used at certain stages } \\
\text { of the life cycle project and during the project life cycle as a whole. }\end{array}$ \\
\hline Sensitivity analysis project & $\begin{array}{l}\text { Determining the degree of stability of the project in relation to possible changes in the conditions } \\
\text { of its implementation. }\end{array}$ \\
\hline $\begin{array}{l}\text { Analysis of the indicator } \\
\text { limit level }\end{array}$ & $\begin{array}{l}\text { Determining the degree of stability of the project in relation to possible changes in the conditions } \\
\text { of its implementation. }\end{array}$ \\
\hline $\begin{array}{l}\text { Construction method } \\
\text { decision tree project }\end{array}$ & $\begin{array}{l}\text { A method that evaluates the most probable values of innovation results depending on the options } \\
\text { for implementing the innovation; it allows you to calculate the mathematical expectation of } \\
\text { results for each of the options for implementing the innovation. }\end{array}$ \\
\hline
\end{tabular}

Source: based on (Yakovets, 2014)

expects that the management of the company will use the investment for the rapid development of its enterprise.

Identifying the features of venture financing is the first step towards defining and systematizing ways and measures to minimize, avoid and prevent risks that arise during the production of new knowledge and new technologies.

Studies show that different areas of the economy apply similar risk reduction mechanisms. So by combining known risk mitigation measures management strategies can be distinguished risks of venture investment.

Venture business is a specific activity that, on the one hand, manifests itself in high risk, and on the other hand, in the chance gets extra profits if successful. That is why there is an urgent need for effective risk management venture financing. Among the considered strategies the most promising strategies for such management are implemented with the participation of third parties, as in in this case the maximum effect

Table 4

\section{Types of risk minimization strategies for venture financing}

\begin{tabular}{|l|l|l|l|}
\hline \multicolumn{3}{|c|}{ Risk minimization strategies for venture financing } \\
\hline Risk diversification strategy & \multicolumn{1}{|c|}{ Funds reservation strategy } & Risk insurance strategy & Strategy risk localization \\
\hline $\begin{array}{l}\text { distribution of invested } \\
\text { capital between several } \\
\text { various objects, industries, } \\
\text { types of activities }\end{array}$ & $\begin{array}{l}\text { Provides installation of the relationship } \\
\text { between potential risks, which affect the } \\
\text { cost project, and the amount of costs, } \\
\text { necessary to overcome negative deviations } \\
\text { in project implementation }\end{array}$ & $\begin{array}{l}\text { transfer of insurance } \\
\text { risks companies, } \\
\text { hedging }\end{array}$ & $\begin{array}{l}\text { isolation (or creation) } \\
\text { small legally independent } \\
\text { venture enterprises }\end{array}$ \\
\hline
\end{tabular}

Source: own study 
from a point is reached view of the national economy.

\section{Conclusions}

Venture capital is a special investment resource in the process of social reproduction, which combines high risk (lack of any guarantees) and uncertainty of the end result with profits, accelerates scientific and technical activities, the transition of the economic system to an innovative type of development. From the standpoint of its functions, venture capital stimulates economic growth and competitiveness in all sectors of the economy, which, in turn, has a positive impact on the realization of national interests and economic security in general and financial security in particular.

High risks and uncertainty of the final aggregate market effect, combined with overhigh profitability of funds invested in innovation, gave reason to consider venture capital as a special factor of innovative economic growth, structural economic recovery.

For Ukraine, the development of venture capital is an opportunity not only to stabilize the economy, but also to provide it with significant growth rates. Ukraine has rather low volumes of investments, which is caused by the lack of trust in investment funds in the population, the instability of the economic situation, in which it is very difficult to predict the future outcome of investments.

\section{References:}

Oliver, N. (1996). Benchmarking Product Development. Working Paper, Judge Institute of Management Studies, University of Cambridge.

Shypulina, Yu. S. (2015). Modern features of venture investment development in industrial enterprises. Economy: the realities of time, vol. 5, pp. 210-214.

Krasovska, O. V. (2013). Venture financing: global trends and the situation in Ukraine. Kyiv: Cone-Yu.

Zinchenko, O. P., Ilchuk, V. P., et al. (2004). The state of development of organizational forms of venture entrepreneurship and its infrastructure in the countries of the world and in Ukraine. Kyiv: NDESEP.

Ukrainskyi venchurnyi portal [Ukrainian venture portal]. Available at: http://www.ventu.org

Parubchak, I., \& Hrynyshyn, H. (2020). Features of public administration in shaping strategy of venture investment of business enterprises. Baltic Journal of Economic Studies, vol. 6, no. 4, pp. 125-132. doi: 10.30525/2256-0742/2020-6-4-125-132

Antoniuk, L. L. (2000). Venture capital: foreign experience and problems of formation in Ukraine. Kyiv: KNEU.

Petruk, O. M., \& Moshenskyi, S. Z. (2008). Theory and practice of venture financing. Zhytomyr: ZhDTU, PE «Ruta».

Smagulova, R. I. (2006). Upravlenie riskami. Pavlodar.

Yakovets, H. Yu. (2014). Peculiarities of analysis and minimization of risks during the venture financing of innovative enterprises. Bulletin of the Chernihiv State Technological University, no. 4. 